\title{
Entrevista com Alberto da Costa e Silva
}

\author{
Interview with Alberto da Costa e Silva \\ Eliane Veras Soares \\ Remo Mutzenberg*
}

\begin{abstract}
Alberto da Costa e Silva é membro da Academia Brasileira de Letras, escritor, historiador e diplomata, Doutor Honoris Causa em Letras pela Universidade Obafemi Awolowo (ex-Universidade de Ifé), da Nigéria, em 1986, e em História pela Universidade Federal Fluminense em 2009. Como diplomata, entre outras atividades, representou o Brasil em numerosas reuniões internacionais, tendo sido delegado do Brasil na reunião da Comissão Econômica das Nações Unidas para a África, em Adis Abeba, em 1961. Foi, também, embaixador em Lagos, Nigéria (1979-1983) e cumulativamente em Cotonu, República do Benim (1981-1983). Sua vasta produção bibliográfica inclui livros de poesia, ensaios, antologias, memórias, literatura infanto-juvenil e história, dentre os quais destacamos A enxada e a lança: a África antes dos portugueses (1992); As relações entre o Brasil e a África Negra, de 1822 à $1^{\text {a }}$ Guerra Mundial (1996); A manilha e o libambo: a África e a escravidão, de 1500 a 1700 (2002); Um rio chamado Atlântico: a África no Brasil e o Brasil na África (2003); Francisco Félix de Souza, mercador de escravos (2004); Das mãos do oleiro (2005); O vício da África e outros vícios (1989); Um passeio pela África (2006) e A África explicada aos meus filhos (2008).
\end{abstract}

\footnotetext{
* Eliane Veras Soares é doutora em Sociologia pela UnB, com pós-doutorado no Centro de Estudos Africanos (ISCTE/IUL), em Lisboa, Portugal, professora do Departamento de Sociologia e do PPG em Sociologia da Universidade Federal de Pernambuco, em Recife, PE<elianeveras1@gmail.com>. Remo Mutzenberg é doutor em Sociologia pela UFPE, pós-doutorando no Centro de Estudos Africanos (ISCTE/IUL), em Lisboa, Portugal, e professor do Departamento de Sociologia e do PPG em Sociologia da Universidade Federal de Pernambuco, em Recife, PE <remutz@gmail.com>
}

\begin{tabular}{|l|l|l|l|l|l|}
\hline Civitas & Porto Alegre & v. 14 & n. 1 & p. 11-26 & jan.-abr. 2014 \\
\hline
\end{tabular}


Na tarde do dia 19 de abril de 2011, o acadêmico, diplomata e historiador Alberto da Costa e Silva concedeu-nos, na Biblioteca da Academia Brasileira de Letras, uma entrevista em que começou por questionar o próprio ponto de partida dos entrevistadores. Por isso mesmo ela não se inicia de modo convencional com uma pergunta, mas com um comentário crítico do entrevistado em relação ao título da pesquisa desenvolvida pelos pesquisadores, Cultura política e democratização para além do sistema político: um diálogo entre o Brasil e países africanos de língua oficial portuguesa. Vamos a ela.

Alberto da Costa e Silva: Eu não acho que no mundo haja uma tradição democrática. Que tradição democrática tem a Alemanha ou a França? Que tradição democrática tem a Itália? Quando se olha para história desses países, a democracia deles é tão jovem ou mais jovem que a do Brasil. Quando se comparam essas tradições, percebe-se que toda democracia não é completa, não é perfeita, não é total, possui apenas determinados parâmetros democráticos. $\mathrm{E}$ quando se observa o Brasil do século 19, a partir de 1840 até 1889, e o compara com os países europeus, verifica-se que nós éramos muito mais democráticos do que a França e a Alemanha. Talvez não fossemos mais democráticos do que a Inglaterra. Mas, tirando os países escandinavos e a Inglaterra, todos os demais tinham uma carência democrática muito grande e viveram mais tempo sob ditaduras, sob governos autoritários, do que sob governos democráticos. A França conta com muito menos anos de liberdade, de livre expressão do pensamento, do que o Brasil. Penso que partimos de pressupostos equivocados. Eu não sou sociólogo, sou só observador. E identifico que era mais ou menos assim. Com relação à África põe-se o problema: o que era democracia na África? Em que medida comunidades nas quais as decisões eram tomadas por consenso eram menos democráticas do que sociedades em que as decisões eram tomadas por parlamentos, pela representação? Havia, na África, sociedades autocráticas e até tirânicas e havia sociedades bastante livres e até muito mais livres do que determinadas sociedades europeias. Tendemos a generalizar muito sobre assuntos como este. Durante todo o governo de Dom Pedro II, os republicanos fizeram propaganda como quiseram, nunca foram constrangidos nem coibidos. E você pode comparar isto com os dois Napoleões na França ou mesmo com o ancién regime, anterior à Revolução Francesa. De maneira que tenho um pouco de dificuldade para tratar de assuntos contemporâneos, porque não sou politicamente nem correto, nem incorreto: sou cismático.

Eliane Veras: Uma das coisas que me impressionou na leitura do seu livro A África explicada aos meus filhos foi o fato de sentir que o senhor queria responder a questões para se contrapor ao senso comum. 
Alberto da Costa e Silva: Exato. Por exemplo, a primeira pergunta [do livro] é logo: A África é uma área de conflitos? É e não é, depende da região e depende do momento. Todas as áreas do mundo são áreas de conflito. $\mathrm{O}$ professor Alceu Amoroso Lima costumava dizer que estamos sempre em crise; quando não estivermos em crise é porque estamos mortos. Estamos sempre em crise. A crise é da natureza das sociedades humanas. Quando se olha determinada região do mundo, e no caso especifico a África depois da descolonização, a tendência é ver o que está dando errado e ninguém se preocupa com o que está dando certo. E o que está dando certo às vezes se pode ver no próprio meio do que está dando errado. Por exemplo, você pode estar numa região com uma guerra civil e, ao mesmo tempo, as crianças irem todos os dias à escola, arrumadinhas, bem vestidas, bem calçadas, de meias, de sapatos. Todos os dias e a aula a funcionar perfeitamente bem. Mas a criança ir para escola todos os dias e a escola funcionar perfeitamente bem não nos dão notícia. Não há tampouco estudioso interessado em estudar as crianças que vão todos os dias para a escola e as famílias das quais estas crianças saem. Além disso, nós temos uma tendência para projetar, em relação aos outros, a nossa maneira de viver. A nossa concepção de casa é diferente da concepção de determinados povos africanos. Eu, por exemplo, conheci em Camarões um senhor que era dono da maior rede de supermercados do país, ele tinha uma dúzia de supermercados em diferentes cidades dos Camarões. Morava num quarto e sala conjugado, mas tinha dois automóveis Rolls Royce. Quer dizer, a concepção dele de conforto, de bem estar e de status é diferente da nossa. Ele não tem necessidade de morar numa grande casa. Ele não vive na casa, vive na rua, vai em casa dormir. Essas diferenças de conceitos faz com que nós façamos julgamentos equivocados sobre os outros povos. Portanto, nesse livro que eu escrevi para adolescentes que estão entrando na universidade, a minha ideia era desmanchar, que eu acho que eu consegui pelo que a senhora disse, desmanchar um pouco essas ideias feitas. A África é uma área de conflitos? É; e também é uma área de solidariedade.

Remo Mutzenberg: $\mathrm{O}$ senhor assentou também a própria ideia equivocada de pensar África como unidade...

Alberto da Costa e Silva: O conceito de africano é como o conceito de bárbaro, como o conceito de estrangeiro, como o conceito de americano ou de europeu ou de asiático. É uma invenção dos outros. Nenhum africano se via como africano. Eles se viam como homem da sua aldeia, um homem do seu país, um homem do seu reino, um homem que era súdito de determinado rei ou de determinado imperador, que pertencia a uma família, a uma linhagem, a um clã, a um grupo linguístico. Ele não se via como africano; é visto de fora 
que ele passa a ser africano. São grupos muito distintos uns dos outros, como de resto os europeus também são distintos uns dos outros. Um sueco é muito diferente de um português, e um inglês de um russo. Mas há algo que é comum aos europeus, como há algo que é comum aos povos africanos, é que por trás dessa diversidade cultural há uma unidade cultural. Aliás, há uma unidade cultural no ser humano como um todo. Nós temos as mesmas respostas para determinados problemas no interior da Sibéria, na Mongólia Exterior, no Peru ou em Nova Iorque. Nós fazemos as moringas do mesmo jeito. Eu só conheço um tipo de moringa, ela pode ter a barriga mais ampla ou menos ampla, pode ter o gargalo largo ou mais estreito, mas ela tem essa forma, para conter água. Uma vasilha tem uma certa forma, uma colher tem uma certa forma, um garfo a mesma forma por toda a parte. Pode haver diferenças de desenho artístico, mas a forma essencial é a mesma. Quer dizer, o ser humano responde a determinados desafios da mesma maneira onde quer que ele se encontre. E dentro de determinadas áreas geográficas, onde há contatos, é normal que se desenvolva uma cultura geral que está em todas as culturas particulares. Determinados conceitos de família, determinados conceitos de dignidade, determinados conceitos de guerra, determinadas armas. O índio brasileiro fazia o mesmo arco que o guerreiro do Mali e que o mongol de Gengis Khan, um era maior e o outro era menor, mas é o mesmo princípio, não há uma diferença básica na forma essencial do instrumento. Então, ao lado dessa diversidade extrema, há uma certa unidade.

Que existe a diversidade, existe. Eu dou no meu livro um exemplo que sempre me pareceu muito evidente, que é a condição dos gêmeos entre os iorubás e os ibos que são vizinhos (Silva, 2008, p. 17). A situação do divórcio da mulher varia de uma cultura para outra; o divórcio do homem também. A propriedade particular da mulher dentro do casamento, que é plena em determinadas áreas, não existe em outras. Há muitas diferenças de acordo com as culturas, mas nós temos a tendência de aplicar a todos o mesmo relato.

O mesmo se passa com religião. Nós, no Brasil, temos a impressão de que todo mundo na África venera os orixás. Os orixás são venerados por um pequeno grupo que tem uns vinte milhões de pessoas no sudoeste da Nigéria e sudeste da República do Benim... E só! No resto da África ninguém sabe o que é orixá. Existem outros deuses, outras divindades, cada grupo tem divindades próprias e, às vezes, estamos diante de sistemas cosmológicos e religiosos extremamente complexos. Povos vizinhos podiam ter deuses conflitantes. Mas, por trás dessa diversidade espantosa de religiões, havia uma certa unidade, porque em quase toda a África ao sul do Saara se acreditava num deus criador, todo poderoso, o deus que criou o mundo, mas dele depois 
se desinteressou. Desinteressou-se não é o verbo mais próprio, mas é o que me ocorreu agora para dizer que ele simplesmente não mais se ocupou com o mundo. Ele o criou e pronto, estava criado; que os outros deuses, que as outras divindades cuidassem desse mundo. De maneira que ninguém apelava para o deus supremo para a solução dos seus problemas. As pessoas apelavam para os deuses particulares, que são, em geral, deuses locais, deuses do grupo, deuses que habitam uma área, uma montanha, um pedaço de rio, uma parte de rio. Não é a montanha que é um deus, como os europeus pensaram quando chegaram à África. O deus não era a montanha: morava nela ou nela podia ser venerado. Quando não se apelava para um deus da natureza, pedia-se ajuda aos ancestrais. Os antepassados têm muita força, os antepassados são poderosos e grande parte desta força vem de nós, dos descendentes, na medida em que, com as nossas oblações, com as nossas preces, fortalecemos os antepassados. Por isso que em toda África é uma benção ter filhos e uma maldição não os ter. Se você tiver filhos e netos e bisnetos, você terá alguém que o recordará e rezará por você. Você estará vivo na eternidade. Quando, porém, você não tiver mais descendentes, você desaparecerá..

Eliane Veras: Finitude...

Alberto da Costa e Silva: É a finitude. Essa é uma ideia que existe em quase toda a África subsaariana. E que convive com a pluralidade de crenças. Em algumas regiões, os deuses lutam entre si. Minha mulher traduziu um romance, A flecha de Deus, do escritor nigeriano Chinua Achebe (2011), que se passa numa aldeia...

Eliane: É a continuidade de $O$ mundo se despedaça (Achebe, 2009)?

Alberto da Costa e Silva: Não, não é continuidade porque são outras as personagens, mas é, digamos assim, o que se passa no momento seguinte. E uma das coisas curiosas é a luta entre os deuses, a luta entre os vários deuses, porque quando um deus deixa de atender o seu devoto, este o descarta. Se esse deus não serve mais, procura-se outro. O que para nós é absolutamente incompreensível, não é? Lendo o livro, você vê: nós resolvemos adotar esse deus porque achamos que ele é bom. E há uma espécie de luta entre deuses. Isso parece estranho, mas se você for ao Velho Testamento é disso que ele trata: da luta do deus dos judeus contra os outros deuses que queriam conquistar o povo judaico. Jeová havia escolhido aquele pequeno povo para ser o seu povo e exigia ser o único deus por ele adorado.

Por cima dessas diferenças, houve um processo homogeneizador, o processo colonial. Ainda que a África estivesse dividida entre ingleses, franceses, alemães, portugueses, italianos e belgas, havia um fio condutor para todos eles, que era trazer os africanos para o que se chamava de modernidade, 
em última análise, para trazer os africanos para fim do século 19, para fazer uma espécie de operação em que se retiravam as pessoas do passado e as traziam para o presente. Então, temos, primeiro, o impacto das armas de fogo, que já começa no século 16 . Temos o impacto do barco à vela, do barco a vapor, dos caminhos de ferro, da escola, do aprendizado para ler, temos o impacto...

Eliane: ... Da religião...

Alberto da Costa e Silva: Da religião, tanto do islamismo que veio do norte do deserto, quanto do cristianismo a partir das praias do Atlântico. Temos o impacto da mudança de línguas gerais, da passagem do suaíli, do hauçá ou do mandinga para outras línguas de contato como o inglês, o francês, o português. Temos o choque de uma forma diferente de cultura, que era uma forma de cultura carregada de prestígio, de prestígio e de poder, não é verdade? Excetuado o caso português, da África do Sul e de enclaves no Senegal, a presença europeia na África só deixa de ser uma presença puramente comercial de pequenos entrepostos - que pagavam impostos aos reis africanos, e que, portanto, eram súditos dos reis africanos. A Europa só se assenhora realmente da África durante pouco mais de cinquenta ou sessenta anos, de 1900 a 1950, 1960. O período colonial foi, assim, curto, mas o seu impacto foi muito violento, ainda que não atingisse de pronto toda a África. Houve lugares na África que, até a segunda metade do século 20, nunca viram um homem branco, sobre os quais nunca o poder colonial se exerceu de fato, que nunca tiveram cadernetas de identidade, que nunca ouviram falar em igreja. $\mathrm{O}$ grande elemento disciplinador esteve baseado em três máquinas: a bicicleta, a máquina de costura manual - sabe, aquela pequenininha que tinha muito no sertão, ainda me lembro de quando eu era menino, tinha muito no sertão do Ceará, a máquina que não era de pé, era a Singer de mão, que os costureiros levavam nas costas - e o rádio de pilha. Sem eletricidade, o rádio de pilha teve uma função na África que até hoje não foi estudada. Por que é que a máquina de costura foi tão importante? Porque ela foi uma poupadora de trabalho extraordinária. E por que é que a bicicleta foi importante? Porque a bicicleta chegava a lugares aonde o cavalo não chegava, nem o automóvel, nem o caminhão.

Eliane: ... Estou me lembrando da cena no livro do Chinua Achebe quando o primeiro branco chega na aldeia ibo, ele chega de bicicleta, não é isso?

Alberto da Costa e Silva: É isso mesmo. A bicicleta teve esse papel. Então nós nos preocupamos com a imprensa, com os navios de guerra e esquecemos que essas coisas menores, aparentemente menores, foram muito mais eficientes no processo de mudanças que outras. Vocês são sociólogos, eu 
não sou. Já pensou em escrever a sociologia do forno? Desse forninho, como é que se chama?

Eliane: ... Microondas?

Alberto da Costa e Silva: Microondas! Ele mudou a vida de milhões de pessoas. Milhões de pessoas não precisaram mais acender o fogão... Que revolução isso representou? Ninguém escreveu sobre isto. O Remo está preocupado com os movimentos sociais, a senhora, eu não sei com que está preocupada. (risos)... Eu queria que pessoas se preocupassem com coisas mais objetivas, por exemplo, o papel da tia solteira na sociedade brasileira. Não há um ensaio sobre a tia solteira na sociedade brasileira. A tia solteira na sociedade brasileira para mim é fundamental para a organização familiar. Pensem bem... e vão verificar que eu tenho razão.

Então é preciso, com relação a África, termos certos cuidados. Por exemplo, quando eu era embaixador na Nigéria, havia mais de uma dezena de firmas brasileiras trabalhando lá. Um dia, o gerente de uma dessas firmas me disse: "Eu estou muito aborrecido. Eu descobri que o Maicon, o meu chofer, é um mentiroso. Há uns seis meses, ele me pediu para ir à aldeia dele, porque a mãe tinha morrido. Há uns dois meses, ele voltou a me pediu pra ir à aldeia, para o enterro da mãe. E, ontem, novamente alegou que a mãe tinha morrido e precisava assistir as cerimônias fúnebres". Mas o Maicon não está mentindo - disse eu. E o gerente cortou-me: "Uma pessoa não pode morrer três vezes". Ao que retruquei: É que ele tem três ou quatro mães. Tem várias mães, porque todas as mulheres do pai dele são mães, e ele foi criado por todas, a meninada era filha de todas elas. Você sabia qual era a sua mãe de verdade, a mãe de verdade naturalmente tinha um carinho especial e um amor especial pelo próprio filho e o favorecia sempre que pudesse, isso é óbvio, isso é normal, mas ela tinha obrigações para com as outras crianças também e as outras crianças se apoiavam nela também.

Eliane: E como se iniciou o seu interesse pela África?

Alberto da Costa e Silva: Com Gilberto Freyre, com Casa grande e senzala. Quando li Casa grande e senzala, tinha uns quinze ou dezesseis anos, em torno de 1947. Foi um professor meu quem me indicou o livro. Acabei de ler o livro e disse para mim mesmo: mas esse livro não termina. Está inacabado. Esse livro me diz que é impossível compreender o Brasil sem saber da África. O que esse livro ensina basicamente é que nós somos uma cultura transplantada. Mas não somos uma cultura portuguesa transplantada. Somos uma cultura portuguesa transplantada, uma cultura africana transplantada e uma cultura indígena transplantada, porque a maioria dos índios também veio de outras regiões. Quando os portugueses aqui chegaram, muitos grupos 
indígenas estavam em processo migratório intenso em todo território. Então, se nós não entendermos isso direitinho, não vamos compreender nada. $\mathrm{E}$ conversei isso com um professor que eu tinha, o linguista Herbert Parente Fortes, e ele me recomendou que eu lesse Os africanos no Brasil, do Nina Rodrigues, e Costumes africanos na Bahia, do Manuel Quirino. ${ }^{1}$ E eu comecei por aí, nesse barco. Pouco depois, caiu-me nas mãos o primeiro volume da Introdução à antropologia brasileira, do Arthur Ramos, que curiosamente era o único dos especialistas em Brasil - que hoje são chamados intérpretes do Brasil - a se interessar verdadeiramente pela África. O Gilberto Freyre tinha a intuição de que a África era importante, mas ele sempre só estudou o africano no Brasil. Mesmo quando faz a viagem que descreveu em Aventura e rotina (1952), ${ }^{2}$ ele vê a África muito por cima. Ele estava preocupado com o Brasil, estava preocupado em saber o que havia de Brasil na África e da África no Brasil, mas não da África por si só.

Então comecei a me interessar pela África e ler tudo que me caía nas mãos sobre a África, que era muito pouco. Mas a África tinha uma vantagem extraordinária, que ainda tem: ela acende a imaginação, liberta o campo da imaginação. Quando eu entrei para o Itamaraty, em 1956, eu descobri uma coisa extraordinária, na biblioteca do Itamaraty está a do Barão do Rio Branco, e este tinha em suas estantes praticamente todos os livros portugueses e italianos, do século 15 e 16, que tratavam da África dos viajantes. Está tudo lá. E eu comecei a ler o Duarte Pacheco Pereira, o Valentim Fernandes, o Cadamosto, o João de Barros. Fui, digamos assim, colocando as pecinhas no meu quebracabeça. A minha ida para Lisboa, em 1960, coincidiu com o início do grande momento da história da África no mundo. Então caiu a sopa no mel, e passei a mandar buscar na França e na Inglaterra os principais livros que saiam sobre a África. E como o pessoal do Itamaraty sabia que eu gostava da África, me mandaram para África, me mandaram para a Nigéria, me mandaram para tudo que era cerimônia de independência, reunião internacional de cacau, de café ou da Comissão Econômica. Havia alguma coisa em Adis Abeba ou em Abidjan, para lá ia o Alberto da Costa e Silva. Comecei a fazer algo que acho ser essencial: confrontar o que se lê com o que se vê, e aprender a ver de olhos limpos. Comecei então a ler com malícia, a virar pelo avesso os textos que tinha diante de mim. Os autores ingleses e franceses do século 19,

Lembramos que Casa grande e senzala, de Gilberto Freyre, foi publicado em 1933, Os africanos no Brasil, de Nina Rodrigues, em 1932 e A raça africana e os seus costumes na Bahia, de Manuel Quirino, em 1919.

2 A terceira edição de Aventura e rotina, publicada em 2001, contém prefácio de Alberto da Costa e Silva. 
por exemplo, são riquíssimos de informações, mas são preconceituosos, assim como os portugueses no século 16 também eram, ainda que menos. Os portugueses do século 19 são muito mais preconceituosos do que do século 16 , o mesmo se dando com os ingleses e os franceses. Isso porque o europeu se foi convencendo de sua superioridade sobre os demais povos. Acreditaram nisso. E os brasileiros também: o padre Vicente Ferreira Pires é de um preconceito, de uma má vontade extraordinária com relação aos africanos, mas o livro dele é muito importante. Como esses livros são muito importantes? Porque os seus autores sabiam ver, eles sabiam, sabiam ouvir, sabiam desenhar, sabiam descrever. Eles aprendiam desde a escola primaria a fazer cópia, a fazer ditado, coisas que hoje as crianças não aprendem mais... A desenhar, a gente não tinha jeito nenhum para desenhar, mas era obrigado a reproduzir esta mesa com este livro, aquela caneta e o caderno. Se, na África, tinham que reproduzir uma cubata, eles reproduziam. Não era uma obra de arte, mas a essência da forma estava presente. E eles sabiam descrever. Agora, o que é que temos de fazer ao ler esses autores? Temos de ler de cabeça para baixo, virando-os do avesso, para ver como era aquilo mesmo que estavam observando, o certo e o errado. Confrontando o que vários deles dizem sobre o mesmo assunto, é possível traçar-se um retrato de como era a realidade em determinado momento.

Por tudo isso, eu me apaixonei pela África. Escrevi um livrinho, que publiquei em Portugal com o nome de $O$ vício da África. Que reflete exatamente isto: a África vicia. As pessoas que vão viver na África se queixam imensamente dos problemas que encontram, das dificuldades que têm. Mas, ao saírem da África, ficam com saudades da África e querem voltar para lá. A África tem uma espécie de grude, um grude esquisito, estranho... mas que pega a gente.

Eliane: O senhor acha que foi a sua experiência de vida em África que possibilitou esse olhar mais crítico?

Alberto da Costa e Silva: Não, eu acho que já tinha um olhar mais crítico antes, acho que o que a minha estada na África, as viagens que eu fiz pela África e os três anos e meio que eu morei em Lagos não desenvolvem em mim um olhar mais crítico, mas me fizeram mais humilde, me ensinaram a perceber a diferença na concepção de vida que têm as pessoas. Vou the contar um caso curioso, uma quase anedota. Um dia eu cheguei em casa, e minha mulher, com a cara muito divertida, me contou: "Alberto, hoje se passou algo extraordinário". Ela dava aulas de francês para a mulher de um ministro nigeriano. E continuou: "Amina, a minha aluna, disse-me: 'Vera, agora que somos amigas, quero lhe fazer uma pergunta que eu sempre quis fazer a uma mulher ocidental. Como é que vocês aguentam ser a única mulher 
de um homem? Os homens são muito chatos, os homens dão muito trabalho". E minha mulher acrescentou: "Eu nunca tinha pensado dessa perspectiva. Mas ela não deixa de ter razão".

Remo: Eu me lembrei de um documentário da TV Brasil, Nova África, em que o senhor afirmava que a fronteira oriental do Brasil é a África. Essa relação entre Brasil e África tem crescido recentemente. Como é que o senhor vê essas mudanças que estão ocorrendo nos últimos dez, quinze anos? A presença da África hoje é muito mais intensa aqui, e também a presença dos brasileiros em África.

Alberto da Costa e Silva: Houve um grande interesse pela África, no Brasil, no fim dos anos 1950 e início dos anos 1960. Foi a época em que nós recebemos muitos estudantes africanos, alguns dos quais depois eu fui encontrar na África. Outro dia mesmo, veio aqui um governador de um estado nigeriano e trazia como assessor um desses rapazes que estudou no Brasil. Quando estava na Nigéria, conheci médicos formados no Brasil. Foi realmente um período de grande atenção que o Brasil teve pela África e durante o qual a África olhou muito para o Brasil. Olhou muito para o Brasil porque o Brasil foi responsável por uma política de proteção aos produtos primários, sobretudo café e cacau. O Brasil praticamente congregou os países latino-americanos produtores de cacau e de café, e com os países africanos que eram grandes produtores dessas matérias-primas, formaram o que podemos chamar de cartéis de produtores, semelhantes à Opep em matéria de petróleo. Essa política fez com que o Brasil fosse muito conhecido, se tornasse muito importante para os países africanos que se estavam independizando. E era muito curioso, porque nas festas de independências, em geral, só havia um país latino americano, só havia dois países americanos, que eram os Estados Unidos e o Brasil. Às vezes havia três, Canadá, Estados Unidos e Brasil. E era muito raro que estivesse Cuba ou que estivesse o México, mas em geral o Brasil estava sempre presente, porque o Brasil era uma referência para as elites africanas enquanto um país tropical, enquanto um país colocado abaixo do trópico de Câncer. Posteriormente esse interesse se esvaiu, mas foi ressuscitado no governo Médici, em 1972, quando o Brasil voltou a se preocupar intensamente com a África e fez grandes avanços em suas relações com o continente africano. Para citar alguns poucos exemplos, ajudamos a criar faculdades de Medicina em universidades africanas, tínhamos instrutores de pilotos de avião na África e a Nigerian Airlines treinava os seus pilotos no Brasil, empresas brasileiras de engenharia operavam em vários setores, capitais brasileiros se associavam a africanos em empreendimentos agrícolas e industriais. Realmente houve um grande avanço nas relações Brasil e a África que se estendeu até 1982 ou 
1983. Aí aconteceu algo curioso: com a redemocratização brasileira diminuiu o interesse pela África. Os militares percebiam a África do ponto de vista geopolítico. Eles tinham a percepção de que a África era nossa fronteira leste, de que Angola, Nigéria, Gabão, Togo, Benim eram tão importantes para nós quanto Bolívia, Peru, Colômbia e Venezuela, que a nossa prosperidade dependia da prosperidade desses países vizinhos.

A esse período áureo, seguiu-se um certo desencanto com o continente africano, pelo qual não foi só o Brasil o responsável, mas também a grande crise de perda de esperanças que ocorreu na África. A desesperança começa na África no inicio da década de 1980. Começou a tornar-se claro para os africanos que a descolonização não tinha trazido os resultados que as pessoas esperavam em matéria de bem estar, de progresso e de liberdade. Os governos ditatoriais se tornaram regra na África. Assim como o desequilíbrio entre as cidades e o campo, entre burocracia inchada do governo e o desamparo das populações interioranas. Todos esses países eram plurinacionais, com várias nações que muitas vezes não logravam entender-se. A questão não é fácil, como mostram países europeus que não conseguiram resolvê-la. A Espanha não o logrou, nem o Reino Unido. Na França, de vez em quando o problema põe a cabeça de fora, e na Itália também. Para agravar a situação, a década de 1980 caracterizou-se pela depressão econômica, tanto no Brasil quanto para a África. No caso africano, essa depressão foi acentuada pela frustração das expectativas.

De alguns anos para cá a situação começou a mudar. Mudou o Brasil e mudou a África. O Brasil saiu de uma situação de desânimo para um estado de euforia. E o mesmo se passou com a África. Alguns países se redemocratizaram, outros se semi-redemocratizaram ou se redemocratizaram parcialmente. Mas, de maneira geral, excetuados alguns poucos países onde continuam ditadores ferozes, na maioria da África houve uma recuperação das liberdades essenciais. Vive-se hoje um ambiente muito menos opressivo do que há dez ou vinte anos atrás. Tudo isso trouxe um renovar de interesse da África pelo Brasil e do Brasil pela África. O comércio cresceu, assim como as relações culturais. Hoje, no Brasil, nota-se um interesse muito grande pelos estudos africanos. Antigamente, eu fazia uma conferência sobre África para vinte, trinta pessoas... Agora, aparecem trezentas. Os auditórios estão cheios, há uma curiosidade enorme para conhecer um pouco do passado, que é do que eu trato, do continente. Cuido da história não porque ela é fonte de ensinamento. A história não nos melhora moralmente, nem dá exemplo de coisa nenhuma, ou melhor, dá exemplo de tudo, do bom e do ruim. Mas é preciso saber como éramos para saber como somos. Dizia o Eugênio d'Ors, 
um pensador catalão que está muito esquecido, que "lo que fue, és", "o que foi continua a ser", o que não quer dizer que o que é, algum dia foi. O que é pode nunca ter sido, mas o que algum dia foi continua sendo. Então, tenho a impressão, por exemplo, de que ninguém entenderá as políticas dos diversos países africanos sem compreender esse fato essencial, que para um jalofo como para um hauçá, sua primeira fidelidade é com a sua família, seus pais, seus tios, seus avós, seus sobrinhos, seus filhos, seus netos; depois é a linhagem; e, em seguida, o clã e o seu grupo étnico. Só então vem o país, num caso o Senegal, noutro a Nigéria. Não que ele seja menos senegalês ou menos nigeriano do que nós somos brasileiros, mas é sobretudo um jalofo ou um hauçá de determinado clã, linhagem e família. E isso que deflui da história das diferentes culturas africanas, creio que continua enraizada no presente dessas culturas, ao menos naquilo que Almeida Garrett chamava de país real em contraposição ao país oficial.

Remo: Isso está relacionado às próprias dificuldades de constituir os "estados nacionais" nos moldes europeus?

Alberto da Costa e Silva: Essa denominação, "estado nacional”, não corresponde muito à realidade europeia. Os estados da Europa não são, com poucas exceções, nacionais. Desde quando a Suíça é um estado nacional? A Suíça é um estado, pelo menos, trinacional. Estado nacional é Portugal. Com uma só língua e um só povo, praticamente desde o século 12, é um estado nacional. O estado nacional é a invenção de Napoleão, da França que ele queria que fosse um estado nacional. Mas eu tinha uma bisavó, que quando você dizia que ela era francesa, ela corrigia: não sou francesa, sou normanda. Penso que a dificuldade para montar um estado moderno nos moldes de um estado europeu na África é a mesma que tiveram os estados europeus no passado e, de certa maneira, continuam tendo até hoje. O que é preciso é se reconhecer que o estado pode ser plurinacional. Para nós, brasileiros, é complicado, porque, embora nós tenhamos um país com origem muito variada, formado por muitos povos, nós nos vemos basicamente como brasileiros, depois é que nós nos vemos como pernambucanos, mineiros, gaúchos, cearenses, piauienses, brancos, negros, mulatos, cafuzos, caboclos. É num segundo momento. Porque aqui houve uma grande mistura, aqui é difícil você dizer "eu sou somente isso", depois de três gerações no Brasil. Não é comum que alguém possa afirmar que só é descendente de italiano. Diz-se comumente que o povo brasileiro é o resultado do encontro de brancos, índios e negros. É certo? Tenho sérias dúvidas. O processo foi muito mais complexo. Foi no Brasil que muito transmontano conheceu pela primeira vez um algarvio, pois em Portugal nunca se tinham encontrado. Aqui um mandinga viu primeira vez um congo, 
que jamais souberam um do outro na África. A formação do brasileiro foi muito mais complexa: o iorubá misturou-se com o andongo e com o minhoto e este com o andaluz e o caiapó, e um e o outro com o italiano do Veneto e o da Sicília e com o tupiniquim e o bávaro. Um negócio muito mais complicado do que nós pensamos. Na realidade, quando dizemos que, no Brasil, houve a "fusão de três raças", fossem tristes ou não tristes - aliás, nenhuma delas era triste... isso foi uma invenção boba nossa - estamos nos referindo a sucessivos encontros de centenas de culturas que aqui, muitas vezes, se entenderam ou desentenderam pela primeira vez. Porque desentender também faz parte do entendimento, não é verdade? Faz parte do encontro. Então, o processo foi muito mais complexo. Na África, também. Mas lá você pertence a um grupo bem definido, a uma determinada linhagem, ainda que possa ter pai ou mãe de linhagens diferentes e até mesmo de línguas diferentes. No caso de um axante que se case com uma inglesa, por exemplo, o filho dele não é axante, mas inglês. Porque, entre os axantes, o parentesco é exclusivamente matrilinear. $\mathrm{E}$, se o pai for inglês e a mãe axante, ele não é inglês, mas axante. Eu estou dando um exemplo com um europeu, mas o mesmo valeria se o sujeito fosse um fante casado com uma axante. Você pertence a um grupo. No Brasil, se o rapaz for filho de uma italiana com um português, ele não é nem italiano nem português. Ele é brasileiro, não é?

Eliane: Achei muito interessante essa forma como o senhor mostrou essa aproximação e distanciamento do Brasil em relação à África. Existe uma dimensão econômica, a relação econômica do Brasil com a África corresponde à metade da relação econômica do Brasil com a China hoje. Mas na dimensão cultural tem uma coisa muito significativa, e nós estamos sentindo isso na universidade, que é a Lei 10.639/03, que instituiu a obrigatoriedade do estudo da história e da cultura africana e afro-brasileira e nós não conhecemos essa história, essa história não está produzida ainda, há um forte incentivo para a produção desses novos conteúdos. Porque até então a nossa história era aquela, o mito das três raças, e a história do Brasil que a gente aprendia na escola era a história dos portugueses no Brasil, o negro era apenas o escravo. Poderíamos dizer que estamos vivenciando, nesse momento, um momento de reestruturação da nossa identidade nacional, diversa daquela forjada nos anos 1930, fundada na ideia da democracia racial, das três raças que constituem o brasileiro?

Alberto da Costa e Silva: Nunca se deu muita ênfase a essas três raças, porque se você voltar a ler o Sérgio Buarque de Holanda ou o Caio Prado Junior, vai ver que o negro é marginal na obra deles. O Brasil deles é basicamente o Brasil conquistado pelos portugueses, para o qual eles trouxeram o negro 
como trabalhador forçado. O primeiro autor a dizer realmente que o negro foi co-fundador e colonizador do Brasil foi Gilberto Freyre. Foi com ele que começamos a mudar a maneira de olhar para nós mesmos. De repente, nós nos olhamos no espelho e dissemos: "Não somos isto; este espelho está errado". Porque o espelho mostrava um desenho nosso que não correspondia à nossa imagem verdadeira.

O que me espanta é que, apesar da Lei, ainda se ande tão devagar nos estudos africanos, ainda haja universidades que não têm cadeira de estudos africanos. Mas nota-se algo muito positivo: há muita gente jovem estudando história da África. Por quê? Porque história da África passou a representar uma área de expansão profissional importante. As pessoas não estudavam história da África porque não tinham estímulo para isso. Não tinham estímulo até mesmo porque se dizia que a África não tinha importância. Não é isso? Agora, o que é preciso ter cuidado é para não permitir que a história da África e que a história do negro no Brasil sejam transformadas em gueto, sejam deslocadas para uma área muito específica fora do contexto geral da história universal, da história do Brasil. É preciso que a história da África esteja incluída na história universal. Ela tem que ser uma matéria especial na universidade, para formar especialistas, como você forma especialistas em história da América, especialistas em história medieval europeia, especialistas em história moderna. Agora nos cursos de formação é preciso que os grandes capítulos da história da África entrem na história universal, que se estude o Império do Mali como se estuda o Império Romano, que se estude o Reino do Benim no século 16 ou no século 17 como se estuda a França no século 18 e no século 19, como se estuda Portugal no século 16 ou como você estuda a unificação italiana no século 19. Que se estude o processo colonial na África como você estuda o processo colonial nas Américas. Não tratar a história da África como algo marginal.

Eliane: Algo exótico.

Alberto da Costa e Silva: É, em uma história exótica. É preciso incorporar a história da África à história global da humanidade. Como de resto se coloca a história da China, a história da Índia. Agora, no nosso caso do Brasil, a história da África é tão importante quanto a história de Portugal, mas nós não estudamos a história de Portugal separadamente, como uma matéria isolada, na escola secundária. Nós estudamos a história de Portugal dentro da história universal e dentro da história do Brasil. Do mesmo modo, deve-se estudar a história da África dentro da história do Brasil e dentro da história universal. Porque, por exemplo, que a guerra santa muçulmana de Osman den Fodio, no norte da Nigéria, foi importante para o Brasil? Foi importante porque, por causa dela, no fim do século 18 e início do século 19, recebemos grande número de 
iorubás e hauçás, que foram responsáveis por mudanças importantes na vida do negro urbano no Brasil. Não sei se estou sendo claro, mas o que eu tenho medo é de que, assim como antes não se estudava história da África, se passe agora a estudar história da África como uma história menor, lateral, marginal, guetizada, em vez de estudar os grandes momentos da história da África como os outros grandes momentos da história da humanidade. Ao que aspiro é que se estude o antigo Zimbabué como se estuda Pedro Grande da Rússia. Sem perder de vista que o Zimbabué é mais importante para o Brasil do que o Pedro Grande da Rússia!

Eliane: Isso significa uma verdadeira revolução cultural no nosso modo de pensar, não é?

Alberto da Costa e Silva: É, mas o meu medo é esse, o meu medo é que se saia da ignorância completa para guetização, para a transformação da história da África e do africano no Brasil em algo especial que não tem nada a ver com a história mundial como um todo, ou com a história do Brasil como um todo. É preciso que ela esteja incorporada no currículo formativo. Não estou falando do currículo universitário, que é diferente, mas do currículo de formação do curso primário, do curso secundário.

Remo: Isso é uma coisa muito séria, porque pensar a Europa, os Estados Unidos, a América de forma geral sem pensar a contribuição e o papel que a África teve, desde o século 16, nisso tudo, realmente é colocá-la à margem...

Alberto da Costa e Silva: Como uma história de vitrine, isso é o meu medo. Mas tudo isso se conserta com o tempo, mesmo que haja uma tendência inicial nessa direção, essa tendência vai se consertar com o tempo. O fato é que há muita gente jovem estudando história da África. Anteontem fui fazer uma conferência na Universidade Federal Fluminense, em um encontro sobre a história da África, e fiquei muito bem impressionado com o número de moças e rapazes que estão fazendo mestrado e doutorado em história da África. Estão realmente se dedicando. E muitos deles estão indo ao continente africano para investigar nos arquivos. Para estudar. Tudo leva a crer que, após um período em que a história da África esteve entregue à mão de amadores como eu, passe para a mão de profissionais de verdade.

Eliane: Com todos os riscos que isso também pode conter...

\section{Referências}

ACHEBE, Chinua. O mundo se despedaça. Tradução de Vera Queiroz da Costa e Silva. São Paulo: Companhia das Letras, 2009 (Introdução de Alberto da Costa e Silva). 
ACHEBE, Chinua. A flecha de Deus. Tradução de Vera Queiroz da Costa e Silva. São Paulo: Companhia das Letras, 2011.

SILVA, Alberto da Costa e. A África explicada aos meus filhos. Rio de Janeiro: Agir, 2008.

Recebido em: 25 jul. 2013

Aprovado em: 25 nov. 2013

Autores correspondentes:

Eliane Veras Soares

Remo Mutzenberg

UFPE - Departamento de Sociologia

Avenida da Arquitetura, s/n. CFCH, 12 andar

Cidade Universitária

50740-550 Recife, PE 